\title{
PENINGKATAN KEMAMPUAN MENGENAL LAMBANG BILANGAN DENGAN BERMAIN TUTUP BOTOL ANGKA PADA ANAK KELOMPOK A DI KELOMPOK BERMAIN BINA ANA PRASA III SAMARINDA TAHUN PEMBELAJARAN 2017/2018
}

\author{
WAHYUNI \\ PG PAUD, FKIP, Universitas Widya Gama Mahakam Samarinda \\ ( imahhakimah83@gmail.com )
}

\begin{abstract}
Abstrak
This study aimed to improve children's capability in identifying Numeric Symbols by Playing the Bottle Caps Numbers in Group A at Play Groups BinaAna Prasa III Samarinda. This study was classroom action research which is done collaboratively between researcher and classroom teacher. This study conducted for two cycles. Each cycle was held for four meetings. Subject of this study were 15 children from Class A, there were 8 male and 7 female. This study conducted on July - August academic year 2017/2018. Data collection technique used observation and documentation that can be analyzed by looking for the percentage of children's success. The results of this study indicate that the ability of children to recognize the symbol of the numbers 1-10 can be increased through the activities of playing the bottle cap numbers. The increase can be seen from the percentage improvement of children who got the criteria very well. The result before doing a treatment who reached the criteria develops very well at $7 \%$ or 1 child and develops as expected there were 3 children by $20 \%$. In cycle I, the percentage of criteria develops very well increased to $40 \%$ or 6 children and percentage grew as expected $40 \%$ or 6 children. In cycle II, which got the criteria very well also grew, there was an increase to $87 \%$ or 13 children and developed as expected with the percentage of $13 \%$ that was 2 children. It could be concluded that by playing bottle caps numbers, it could improve children's capability in identifying Numeric Symbols in Group A at Play Groups BinaAna Prasa III Samarinda.
\end{abstract}

Key words : Ability in identifying numeric symbols, playing Bottle Caps Number

\section{PENDAHULUAN}

Anak Usia Dini merupakan individu yang memiliki karakteristik yang berbeda satu dengan lainnya. Pada saat ini sedang mengalami perkembangan otak yang sangat pesat dan dikatakan dengan masa emas (golden ages) sampai 80 persen. Masa ini tidak akan terulang lagi. Oleh karena itu, pemberian rangsangan pendidikan pada usia dini yang tepat sangat diperlukan untuk memastikan bahwa setiap anak mencapai perkembangan yang optimal sehingga mereka mempunyai landasan yang kuat untuk menempuh pendidikan selanjutnya (Kemendikbud, 2015: 1). Karakteristik cara belajar anak usia dini sebagai berikut:

(1) Anak belajar secara bertahap;

Cara berpikir anak bersifat khas; (3) Anak-anak belajar dengan berbagai cara; 
(4) Anak belajar satu sama lain dengan lingkungan sosial; dan (5) Anak belajar melalui bermain. Bermain membantu mengembangkan berbagai potensi anak.

Pembelajaran anak usia dini yang diterapkan dalam kelompok bermain didasarkan atas prinsif-prinsif sebagai berikut

(1) Belajar melalui bermain; (2) Berorientasi pada perkembangan anak; (3) Berorientasi pada kebutuhan anak; (4) Berpusat pada anak; (5) Pembelajar aktif; (6) Berorientasi pada pengembangan nilai-nilai karakter;

Berorientasi pada kecakapan hidup; (8) Didukung oleh lingkungan yang kondusif; (9) Berorientas pada pembelajaran yang demokratis; dan (10) Pemanfaatan media belajar, sumber belajar, dan narasumber. (Kemendikbud, 2015: 15).

(2) Menurut Suyadi (2015:22) Pendidikan Anak Usia Dini (PAUD) pada hakekatnya adalah pendidikan yang diselenggarakan dengan tujuan untuk memfasilitasi pertumbuhan dan perkembangan anak secara menyeluruh atau menekankan pada pengembangan seluruh aspek kepribadian anak. Oleh karena itu, PAUD perlu menyediakan berbagai kegiatan yang dapat mengembangkan berbagai aspek perkembangan seperti kognitif, bahasa, sosial, emosi, fisik dan motorik.

Menurut UU Nomor 20 Tahun 2003 tentang Sistem Pendidikan Nasional Bab I Pasal I butir 14 menyatakan bahwa:

“ Pendidikan anak usia dini (PAUD) merupakan suatu upaya pembinaan yang ditujukan kepada anak sejak lahir sampai dengan usia 6 (enam) tahun yang dilakukan melalui pemberian rangsangan pendidikan untuk membantu pertumbuhan jasmani dan rohani agar anak memiliki kesiapan dalam memasuki pendidikan lebih lanjut".

Pendidikan anak usia dini adalah : untuk memberikan stimulasi atau rangsangan bagi perkembangan potensi anak agar menjadi manusia beriman dan bertaqwa kepada Tuhan yang Maha Esa, berakhlak mulia, sehat, berilmu, cakap, kritis, kreatif, inovatif, mandiri, percaya diri, menjadi warga negara yang demogratis dan bertanggung jawab. Dalam hal ini, posisi Pendidikan Nasional berfungsi mengembangkan kemampuan dan membentuk karakter serta peradaban bangsa yang bermartabat dalam rangka mencerdaskan kehidupan bangsanya, 
potensi peserta didik agar menjadi manusia yang beriman dan bertaqwa kepada Tuhan yang Maha Esa, berakhlak mulia, sehat, berilmu, dan cakap. Depdiknas (2007) dalam Suyadi (2015:23-24).

Senada dengan tujuan diatas, Solihudin (1997) dalam Suyadi (2015:24) menyatakan pendidikan anak usia dini adalah memfasilitasi pertumbuhan dan perkembangan anak secara optimal dan menyeluruh sesuai dengan norma-norma dan nilai-nilai kehidupan yang dianut. Melalui pendidikan anak usia dini, anak diharapkan dapat mengembangkan segenap potensi yang dimilikinya kognitif, sosial, emosional, fisikmotorik, dan rasa beragama sebagai dasar-dasar aqidah yang lurus sesuai dengan ajaran agama yang dianutnya.

Sudarna (2014:11-12) Kognitif adalah proses yang terjadi secara internal didalam pusat susunan syaraf pada waktu manusia sedang berpikir. Kemampuan ini berkembang secara bertahap, sejalan dengan perkembangan fisik dan syaraf-syaraf yang berada di pusat susunan syaraf.

Salah seorang yang merumuskan teori yang dapat menjelaskan fase-fase perkembangan kognitif ini adalah teori Piaget. Teori ini dibangun berdasarkan dua sudut pandang yang disebut sudut pandang aliran struktural dan aliran konstruktif. Aliran struktural yang mewarnai teori Piaget dapat dilihat dari pandangannya tentang inteligensi yang berkembang melalui serangkaian tahap perkembangan yang ditandai oleh perkembangan kualitas struktur kognitif. Aliran konstruktif terlihat dari pandangan Piaget yang menyatakan bahwa, anak membangun kemampuan kognitif melalui interaksi dengan dunia sekitarnya.

Menurut Jean Piaget (1972) dalam Sudarna (2014:12) Perkembangan merupakan suatu proses yang bersifat kumulatif. Artinya perkembangan terdahulu akan menjadi dasar bagi perkembangan selanjutnya. Dengan demikian, apabila terjadi hambatan pada perkembangan terdahulu maka perkembangan selanjutnya akan memperoleh hambatan. Piaget membagi perkembangan kognitif kedalam empat fase, yaitu fase sensorimotor, fase praoperasional, fase operasi konkret, dan fase operasi formal.

Untuk mewujudkan tujuan tersebut perlu diadakan suatu pengembangan berbagai kemampuan dasar dan potensi yang ada pada diri anak tanpa melupakan karakteristik cara belajar anak. Pengembangan kemampuan dasar pada diri anak harus dilakukan secara optimal melalui 
pemberian stimulasi pada aspek perkembangan, salah satu perkembangan kognitif, yang harus dikembangkan adalah kemampuan kognitif anak dalam mengenal lambang bilangan. Pada anak usia dini mempunyai peranan penting dalam kehidupan sehari-hari, karena melalui pengenalan lambang bilangan secara sederhana dapat dilihat melalui bernyanyi menyebutkan lambang bilangan, anak juga bisa belajar dari benda-benda yang ada di lingkungan sekitar anak.

Pembelajaran dalam mengenal lambang bilangan 1-10 dapat melalui mengelompokkan benda berdasar ukuran. Pengenalan lambang bilangan dapat dilakukan dengan memasangkan benda dengan pasangannya 1-10. Pengenalan lambang bilangan juga dapat dilakukan dengan mengenal konsep tinggi rendah dengan cara membandingkan 1-10. Pembelajaran dalam mengenal lambang bilangan 1-10 melalui menghubungkan benda konkret dengan lambang bilangan. Pembelajaran dalam mengenal lambang bilangan pada anak usia dini tidak dapat dilakukan secara tergesa-gesa, tetapi harus dilakukan secara bertahap.

Berdasarkan observasi di KB Bina Ana Prasa III Samarinda proses pembelajaran kognitif dalam mengenal

lambang bilangan 1-10 pada pembelajaran hanya menggunakan media atau sumber belajar yang kurang menarik bagi anak, hal ini membuat anak-anak kurang bersemangat dalam belajar sehingga anak-anak hanya sekedar rmenghapal tanpa tahu satu persatu bilangan 1-10. Kemampuan anak dalam membedakan lambang bilangan kadang masih terbalik bilangan 6 dianggap bilangan 9 dan sebaliknya, bilangan 3 dianggap bilangan 5 dan sebaliknya. Sehingga peneliti menyimpulkan dari 15 anak yang terdiri dari 8 anak laki-laki dan 7 anak perempuan, anak yang belum berkembang ada 6 anak mencapai 40\%, dan anak mulai berkembang ada 5 anak mencapai 33\%, dan anak berkembang sesuai harapan 3 anak mencapai $20 \%$, dan anak yang mencapai nilai berkembang sangat baik 1 anak mencapai $7 \%$. Dengan demikian sebagian besar anak-anak KB Bina Ana Prasa III Samarinda perlu dibimbing dalam peningkatan kemampuan mengenal lambang bilangan 1-10.

Melihat permasalahan yang dikemukakan diatas, peneliti tertarik untuk mengambil salah satu cara yang dapat mengembangkan kemampuan dasar kognitif pada anak dalam mengenal lambang bilangan yaitu menggunakan suatu kegiatan bermain 
dengan menggunakan tutup botol angka.

Dengan bermain tutup botol angka diharapkan minat belajar anak meningkat, sehingga berpengaruh terhadap perkembangan kognitif anak. Tutup botol angka merupakan alat bermain yang terbuat dari tutup botol bekas yang diberi angka untuk dimainkan anak. Selain untuk mengenal lambang bilangan, juga dapat dimainkan untuk mengenal bentuk geometri, ukuran, warna, warna tutup botol yang warna-warni sehingga sangat menarik minat belajar anak, membangkitkan semangat belajar dan dapat memanfaatkan barang bekas dengan lebih kreatif dan efektif.

Berdasarkan latar belakang tersebut di atas maka dijadikan landasan peneliti melaksanakan penelitian tindakan kelas dengan judul "Peningkatan kemampuan mengenal lambang bilangan dengan bermain tutup botol angka pada anak kelompok A di KB Bina Ana Prasa III Samarinda".

\section{METOLOGI PENELITIAN}

\section{Desain Penelitian}

Penelitian ini adalah penelitian tindakan kelas (PTK) yaitu penelitian tindakan kelas kolaborasi yang dimaksud adalah kolaborasi atau kerjasama antara peneliti dengan teman sejawat di kelas atau tempat mengajar dengan penekanan pada penyempurnaan atau peningkatan proses dan praktis pembelajaran.

Sedangkan jenis penelitian adalah PTK menurut Arikunto (Dimyati, 2009:112) PTK merupakan suatu perencanaan terhadap kegiatan belajar berupa sebuah tindakan, yang sengaja dimunculkan dan terjadi dalam sebuah kelas secara bersama. Tindakan tersebut diberikan oleh guru atau dengan arahan dari guru yang dilakukan oleh anak. Menurut Arikunto (Dimyati, 2009:115) menyebutkan bahwa istilah penelitian tindakan kelas berasal dari bahasa Inggris, yaitu Classroom Action Research. Penelitian tindakan kelas merupakan kegiatan penelitian yang dilakukan oleh guru di dalam kelas yang sehari-hari dipegangnya. Arikunto (Dimyati, 2009: 117), menyebutkan di dalam penelitian tindakan kelas ada tiga istilah yang membentuk pengertian tersebut, yakni: penelitian, tindakan dan kelas.

1. Penelitian, menunjukan pada suatu kegiatan mencermati suatu objek dengan menggunakan cara atau aturan metodologi tertentu untuk memperoleh data atau informasi yang bermanfaat dalam meningkatkan mutu suatu hal atau masalah. 
2. Tindakan, menunjuk pada suatu usaha/kegiatan yang sengaja dilakukan untuk mencapai tujuan tertentu.

3. Kelas, adalah suatu tempat yang tidak tebatas pada ruang tertentu, tetapi mengandung pengertian pada sejumlah siswa dalam kelompok yang mengikuti kegiatan pembelajaran yang dirancang oleh guru.

Menurut Arikunto at.al(2006:131) penelitian yang digunakan dalam penelitian ini adalah pendekatan yang dugunakan desain deskriptif dan kualitatif. Deskriptif dapat digunakan untuk mengelola karakteristik data yang berkaitan dengan jumlah, rata-rata, mencari presentase keberhasilan. Dan menyajikan data yang menarik dan mudah dibaca, diikuti alur berfikirnya. (grafik, tabel, chart). Kualitatif yang merupakan hasil pengamatan, penelitian tidakan kelas umumnya melakukan proses untuk mengorganisasikan data yaitu sebagai berikut; (1) Permasalahan yang diteliti; (2) Pemilihan sobjek; (3) Pembuatan instrument pengamatan anak dan guru; (4) Melakukan analisis data; (5) Menginformasikan kesimpulan.

\section{Subjek Penelitian}

Subjek penelitian tindakan kelas adalah anak didik pada kelompok A KB Bina Ana Prasa III Samarinda yang berjumlah 15 orang anak, yang terdiri dari 8 anak laki-laki dan 7 anak perempuan tahun pembelajaran 2017/2018.

\section{Objek Penelitian}

Objek penelitian tindakan kelas KB Bina Ana Prasa III Samarinda adalah: Kemampuan anak mengenal lambang bilangan dengan Bermain Tutup Botol Angka.

\section{Waktu dan Lokasi Penelitian}

Waktu dari jam 07.30-10.00 WITA dan lokasi penelitian tindakan kelas akan dilaksanakan di KB Bina Ana Prasa III Samarinda pada anak kelompok A yang berjumlah 15 anak yang terdiri dari 8 anak laki-laki dan 7 anak perempuan. Penelitian ini direncanakan pada semester I(satu) pada tahun pembelajaran 2017/2018 yang terdiri dari dua siklus dan setiap siklus terdiri dari 4 kali pertemuan.

\section{Instrumen Penelitian}

Pelitian tindakan kelas di KB Bina Ana Prasa III Samarinda menggunakan beberapa instrumen penelitian yaitu sebagai berikut:

1) Kurikulum 2013 Nomor 146 Tahun 2014 merupakan pedoman dalam Rencana Pelaksanaan Pembelajaran Mingguan (RPPM) dan Rencana Pelaksanaan Pembelajaran Harian (RPPH). 
2) Rencana Pelaksanaan Pembalajaran Mingguan (RPPM) dan Rencana Pelaksanaan Pembelajaran Harian (RPPH) merupakan rancangan kegiatan pembelajaran yang berisi indikator untuk mencapai hasil belajar anak yang diharapkan sesuai dengan kompetensi inti dan kompetensi dasar pada kukurikulum 2013.

3) Lembar instrument pengamatan guru untuk memantau peningkatan kemampuan guru melaksanakan penerapan dalam mengenal lambang bilangan pada anak dapat dilihat pada lampiran.

4) Lembar instrument pengamatan anak untuk membantu peningkatan kemampuan kognitif anak dalam mengenal lambang bilangan dapat dilihat pada lampiran.

5) Instrumen penilaian untuk anak berupa penilaian anak berupa indikator perkembangan anak yang meliputi.

6) BSB (Berkembang Sangat Baik) dengan nilai 4: Anak sudah paham dan mampu menyelesaikan kegiatan secara tepat dan benar tanpa bantuan guru, sudah paham dan mampu diatas rata-rata, dan sudah terbiasa.

7) BSH (Berkembang Sesuai Harapan) dengan nilai 3: Anak sudah paham dan mampu mengerjakan/ melakukan/ menyelesaikan kegiatan tanpa bantuan.

8) MB (Mulai Berkembang) dengan nilai 2: Lebih sering muncul dari pada tidak, lebih sering terlihat dari pada tidak, lebih sering mampu dari pada tidak.

9) BB (Belum Berkembang) dengan nilai 1: Baru mengenal dan baru mulai, baru sekali muncul, perlu bimbingan.

Dari ke empat aspek diatas maka yang akan dinilai oleh peneliti adalah: 1) Ketepatan anak mengelompokan tutup botol angka $1-5$ \& 1-10; 2) Ketepatan anak memasangkan tutup botol angka 1-10; 3) Kemampuan anak membandingkan tinggi rendah dengan tutup botol angka $1-5$ \& $1-10$; 4) Kemampuan anak menghubungkan tutup botol angka dengan lambang bilangan.

\section{Prosedur Penelitian}

Menurut Arikunto (Dimyati, 2009:124) model penelitian tindakan pada garis besarnya terdapat empat tahapan yang lazim dilalui, yaitu; (1) Perencanaan; (2) Pelaksanaan; Pengamatan/Observasi; dan (4) Refleksi. Prosedur penelitian tindakan kelas di rencanakan hingga siklus 2, yaitu dengan tahapan-tahapan: 


\section{Tahap Perencanaan}

Penelitian tindakan kelas di KB Bina Ana Prasa III Samarinda direncanakan di semester I (satu) pada tahun pembelajaran 2017/2018 dalam dua siklus. Adapun kegiatan yang dilakukan dalam tahap perencanaan di kelompok A KB Bina Ana Prasa III antara lain;

(1) Membuat Rencana Pelaksanaan Pembelajaran Mingguan (RPPM) dan Rencana Pelaksanaan Pembelajaran Harian (RPPH);

(2) Menentukan tema dan sub tema yang akan diajarkan;

(3) Menyiapkan media pembelajaran yang akan digunakan dalam kegiatan bermain tutup botol angka; dan

(4) Membuat lembaran observasi.

\section{Tahap Pelaksanaan}

Pada tahap pelaksanaan, tindakan siklus akan dilaksanakan kegiatan pembelajaran melalui penerapan bermain tutup botol angka untuk meningkatkan kemampuan mengenal lambang bilangan pada anak dengan mengacu pada Rencana Pelaksanaan Pembelajaran Mingguan (RPPM) dan Rencana Pelaksanaan Pembelajaran Harian (RPPH).

\section{Tahap Pengamatan}

Tahapan observasi merupakan kegiatan pengamatan untuk mengetahui tingkat keberhasilan penerapan bermain tutup botol angka untuk meningkatkan kemampuan mengenal lambang bilangan dengan menggunakan pengamatan untuk anak pada setiap tindakan siklus.

\section{Tahap Refleksi.}

Refleksi merupakan kegiatan untuk mengevaluasi aspek penelitian yang belum tercapai agar dapat diperbaiki pada tindakan siklus selanjutnya. Apabila permasalahan belum dapat teratasi pada pelaksanaan tindakan siklus I maka perlu untuk melaksanakan ketuntasan belajar akan dilanjutkan kesiklus berikutnya. Persedur penelitian tindakan kelas menurut Arikunto (Dimyati, 2009:124) dapat dilihat siklus penelitian tindakan kelas berikut ini:

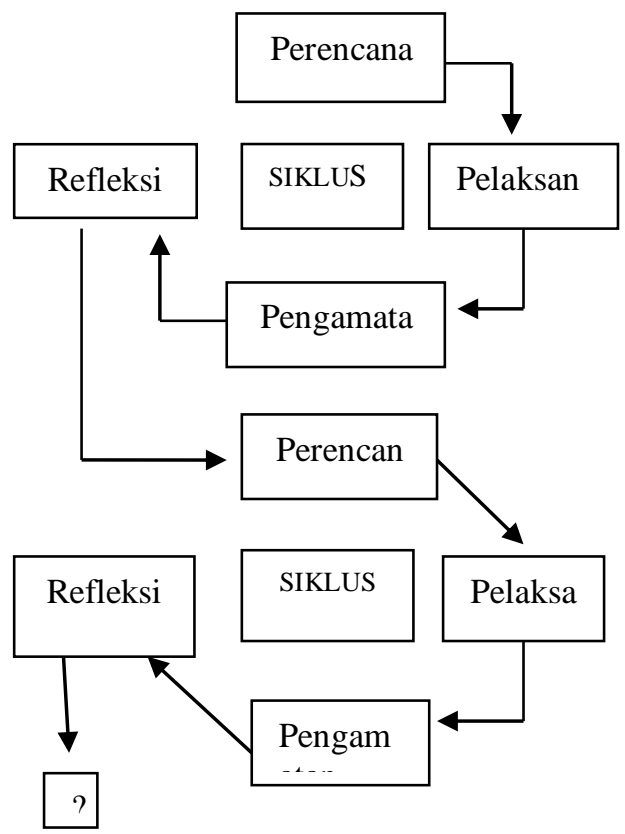

Gambar 1. Siklus Penelitian Tindakan Kelas 


\section{Teknik Pengumpulan Data}

\section{Teknik Observasi}

Dalam teknik observasi cara yang paling efektif adalah dalam melengkapi hasil pengamatan sebagai instrument. Jenis observasi yang akan digunakan dalam penelitian ini adalah observasi langsung yaitu peneliti terlibat langsung dengan objek atau subjek yang diamati atau yang digunakan sebagai sumber data penelitian, sehingga mendapatkan data yang lengkap dan mendalam tentang sesuatu yang sedang diamati. Dalam penelitian ini, observasi dilakukan didalam kelas A. Observasi dilakukan selama pembelajaran berlangsung untuk mengetahui keaktivitasan anak dalam meningkatkan kemampuan mengenal lambang bilangan dengan bermain tutup botol angka.

\section{Teknik Dokumentasi}

Dokumentasi yang digunakan dalam penelitian ini berupa foto-foto pada saat kegiatan pembelajaran bermain tutup botol angka berlangsung. Dokumentasi ini dilakukan untuk memberi gambaran nyata tentang kegiatan anak.

\section{Teknik Analisis Data}

Menurut Arikunto at.al (2006:132) Analisis merupakan usaha untuk memilih, memilah, membuang, menggolongkan, serta menyusun kedalam kategorisasi, mengklasifikasi data untuk menjawab pertanyaan pokok tema apa yang dapat ditemakan/ digunakan pada data, dan seberapa jauh data dapat mendukung tema/arah/tujuan penelitian. Untuk mencari nilai rata-rata, mencari persentase dengan menggunakan tabel.

1. Mencari rata-rata dengan menggunakan rumus:

$\mathrm{X}=\quad \frac{\Sigma X}{\Sigma N}$

Keterangan:

$\mathrm{X}=$ Nilai rata-rata

$\Sigma \mathrm{X}=$ Jumlah semua nilai anak

$\Sigma \mathrm{N}=$ Jumlah anak

2. Mencari keberhasilan siswa dengan rumus:

$\mathrm{P}=\frac{\text { Kategori nilai siswa }}{\text { Siswa }} \times 100 \%$

Menurut Sudjana dalam (Dimyati, 2014:105), data kualitatif dari hasil penelitian dapat disusun dalam bentuk tabel dan langsung ditafsirkan untuk menyusun kesimpulan hasil penelitian. Pengukuran terhadap subjek penelitian menggunakan pedoman dari Ditjen Mandas Diknas 2010 dalam Dimyati (2014:106) dengan kategorisasi sebagai berikut:

1. $\mathrm{BB}=$ Belum Berkembang

2. $\mathrm{MB}=$ Mulai Berkembang

3. $\mathrm{BSH}=$ Berkembang Sesuai Harapan

4. BSB = Berkembang Sangat Baik 


\section{Indikator Ketuntasan Belajar}

Indikator keberhasilan pada pelaksanaan tindakan siklus kegiatan penelitian dalam peningkatan kemampuan mengenal lambang bilangan dengan bermain tutup botol angka dapat dilihat pada tabel skala penilaian.

Tabel 1. Tabel Kriteria Penilaian KB Bina Ana Prasa III Samarinda

\begin{tabular}{|c|c|c|}
\hline No & Jenis Penilaian & $\begin{array}{c}\text { Nilai } \\
\text { Persentase }\end{array}$ \\
\hline 1 & $\begin{array}{c}\text { BB = Belum } \\
\text { Berkembang }\end{array}$ & $0 \%-25 \%$ \\
\hline 2 & $\begin{array}{c}\text { MB = Mulai } \\
\text { Berkembang }\end{array}$ & $26 \%-50 \%$ \\
\hline 3 & $\begin{array}{c}\text { BSH = Berkembang } \\
\text { Sesuai Harapan }\end{array}$ & $51 \%-75 \%$ \\
\hline 4 & $\begin{array}{c}\text { BSB = Berkembang } \\
\text { Sangat Baik }\end{array}$ & $\begin{array}{c}76 \%- \\
100 \%\end{array}$ \\
\hline
\end{tabular}

Persentase keberhasilan anak secara umum pada peningkatan kemampuan anak dalam mengenal lambang bilangan dengan bermain tutup botol angka adalah jumlah anak yang berhasil di bagi jumlah anak sejumlah 15 dan dikali $100 \%$. Dari hasil tersebut dapat diketahui tingkat keberhasilan anak dalam peningkatan kemampuan mengenal lambang bilangan dengan bermain tutup botol angka. Menurut Nana Sudjana (Dimyati, 2014:107) batas ketuntasan secara klasikal dari hasil belajar anak ialah $75-80 \%$. Apabila $80 \%$ dari jumlah anak (12 anak) yang berhasil maka kegiatan penelitian di katakana tuntas.

\section{TEMUAN DAN PEMBAHASAN}

Temuan

Hasil pengamatan kemampuan anak pratindakkan tersebut dapat diuraikan melalui tabel berikut ini:

Tabel 2. Hasil Persentase Keberhasilan Anak Pra Tindakan

\begin{tabular}{|c|c|c|c|}
\hline Skor & Kriteria & $\begin{array}{c}\text { Jumlah } \\
\text { Anak }\end{array}$ & Persentase \\
\hline 4 & $\begin{array}{c}\text { Berkembang } \\
\text { Sangat Baik }\end{array}$ & 1 & $7 \%$ \\
\hline 3 & $\begin{array}{c}\text { Bekembang } \\
\text { Sesuai Harapan }\end{array}$ & 3 & $20 \%$ \\
\hline 2 & $\begin{array}{c}\text { Mulai } \\
\text { Berkembang }\end{array}$ & 5 & $33 \%$ \\
\hline 1 & $\begin{array}{c}\text { Belum } \\
\text { Berkembang }\end{array}$ & 6 & $40 \%$ \\
\hline Jumlah & \multicolumn{2}{|c|}{$15 \%$} \\
\hline \multicolumn{4}{|c|}{ Berdasarkan tabel diatas dapat } \\
\hline
\end{tabular}

disimpulkan bahwa kemampuan mengenal lambang bilangan dengan bermain tutup botol angka masih kurang optimal. Terbukti dengan persentase yang diperoleh anak dalam kriteria berkembang sangat baik belum memenuhi indikator keberhasilan yaitu 80\% dari jumlah anak keseluruhan 15 anak.

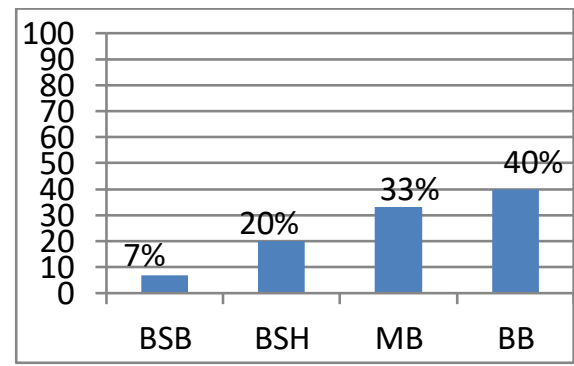

Gambar 1. Diagram Persentase Kemampuan Mengenal Lambang Bilangan 1-10 Pra Tindakan Kreteria Mengenal Lambang Bilangan. 
Berdasarkan diagram diatas dapat disimpulkan bahwa kemampuan mengenal lambang bilangan dengan bemain tutup botol angka pada pra tindakan belum memenuhi indikator keberhasilan $80 \%$.

\section{Hasil Pengamatan Siklus I}

Rekapitulasi Pertemuan 4 ini telah mencapai target keberhasilan karena ada 6 anak yang mencapai nilai berkembang sangat baik yaitu $40 \%$ dan 6 anak yang mencapai kriteria berkembang sesuai harapan $40 \%$ dari jumlah keseluruhan 15 anak. Dilihat dari jumlah anak yang mencapai kriteria BSB dan BSH pada pertemuan ke 4 berjumlah 12 anak dengan persentase keberhasilan yaitu $80 \%$ dengan indikator keberhasilan 80\%. Penelitian ini memperoleh nilai BSB dan BSH dikarenakan anak mampu melakukan kegiatan mengenal lambang bilangan dengan bermain tutup botol angka.

\section{Peningkatan}

kemampuan mengenal lambang bilangan dapat diketahui dari membandingkan persentase yang didapat diawal tindakan hingga pertemuan ke 4 dapat dilihat pada tabel dibawah ini.
Tabel. 3. Rekapitulasi Keberhasilan Kemampuan Mengenal Lambang Bilangan 1-10 Pra Tindakan Sampai Siklus I

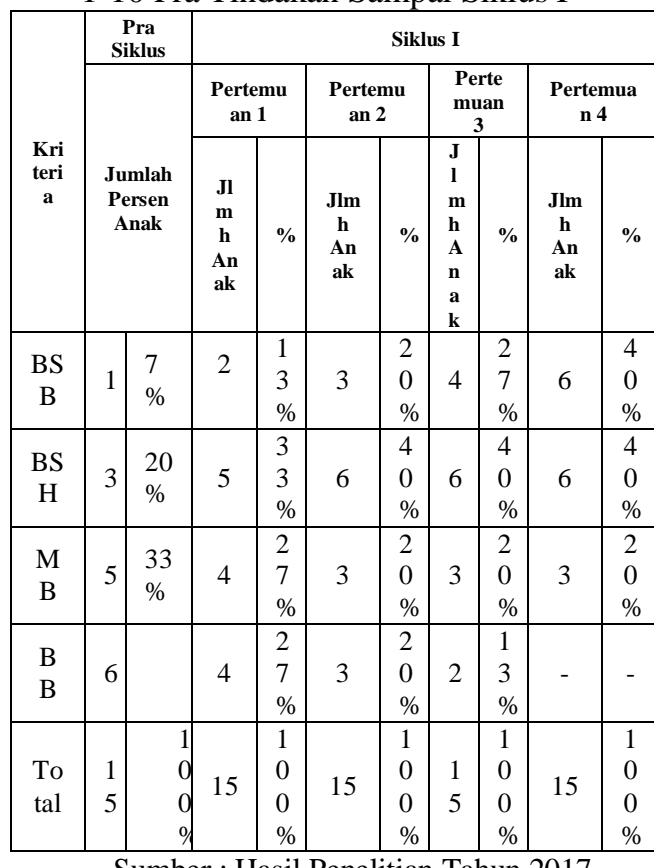

Aspek Penilaian

Pembelajaran Siklus I

a. Hasil penilaian siklus 1 pertemuan 1 dalam peningkatan kemampuan mengenal lambang bilangan dengan bermain tutup botol angka mencapai 43\%. Hal ini menunjukan kemampuan anak mengenal lambang bilangan masih kurang dikarenakan anak masih kurang aktif dalam mengikuti pembelajaran pada kegiatan bermain tutup botol angka.

b. Hasil penilaian siklus 1 pertemuan 2 dalam peningkatan kemampuan mengenal lambang bilangan dengan bermain tutup botol angka mencapai $60 \%$. Hal ini menunjukan bahwa kemampuan anak mulai mengalami peningkatan karena anak sudah mulai 
aktif dalam mengikuti pembelajaran pada kegiatan bermain tutup botol angka.

c. Hasil penilaian siklus 1 pertemuan 3 dalam peningkatan kemampuan mengenal lambang bilangan dengan bermain tutup botol angka mencapai 67\%. Hal ini menunjukan bahwa sudah mengalami peningkatan namun masih kurang signifikan perkembangannya.

d. Hasil penilaian siklus 1 pertemuan 4 dalam peningkatan kemampuan mengenal lambang bilangan dengan bermain tutup botol angka mencapai $80 \%$. Hal ini menunjukan keberhasilan dan ketuntasan belajar.

Ketuntasan belajar tercapai dengan melihat keberhasilan anak pada Siklus I pertemuan 4 dengan kriteria berkembang sangat baik dan berkembang sesuai harapan mencapai keberhasilan 80\% yaitu 12 anak. Dengan demikian ketuntasan belajar tercapai, tapi untuk mendapatkan data yang vailid maka dilanjutkan ke siklus II.

Berdasarkan diagram diatas dapat dilihat peningkatan kemampuan mengenal lambang bilangan yang mendapat kriteria mulai berkembang menurun menjadi $20 \%$ yaitu 3 anak, berkembang sangat baik 6 anak 40\% dan kriteria berkembang sesuai harapan 6 anak $40 \%$. Dengan demikian jumlah anak yang mencapai BSB dan BSH jika dijumlahkan ada 12 anak $80 \%$ dengan demikian ketuntasan belajar tercapai namun masih perlu dilanjutkan kesiklus selanjutnya yaitu siklus II untuk mendapatkan data yang vailid dan mendapatkan hasil yang memuaskan.

\section{Hasil Pengamatan Siklus II}

Pada tahap observasi peneliti dan teman sejawat mengamati secara langsung bagaimana ketepatan dan kemampuan anak dalam mengenal lambang bilangan 1-10 dalam melakukan kegiatan pembelajaran. Pada siklus II untuk mencatat aktivitas anak yang meliputi aspek: ketepatan anak mengelompokkan ukuran tutup botol angka mencapai hasil $80 \%$ ada peningkatan anak berkembang sangat baik yaitu ada 12 anak, ketepatan anak memasangkan tutup botol angka dengan pasangannya mencapai hasil $73 \%$ yaitu 12 anak mencapai nilai berkembang sangat baik, kemampuan anak membandingkan tinggi rendah dengan tutup botol angka mencapai hasil $80 \%$ yaitu 12 anak, dan kemampuan anak menghubungkan tutup botol angka dengan pasangannya mencapai hasil $73 \%$ yaitu 11 orang anak mencapai nilai berkembang sangat baik. Hasil kemampuan mengenal lambang bilangan dapat dilihat pada tabel berikut ini: 
Tabel 4. Hasil Pengamatan Siklus II

\begin{tabular}{|c|c|c|c|c|c|}
\hline \multirow{3}{*}{ No } & \multirow{3}{*}{ Aspek Pengamatan } & \multicolumn{4}{|c|}{ Hasil Pengamatan } \\
\hline & & 4 & 3 & 2 & 1 \\
\hline & & $\%$ & $\%$ & $\%$ & $\%$ \\
\hline \multirow[b]{2}{*}{1} & \multirow{2}{*}{$\begin{array}{l}\text { Ketepatan } \\
\text { mengelompokan } \\
\text { ukuran tutup botol } \\
\text { angka } 1-5 \text {, dan } 1-10\end{array}$} & 12 & 3 & 0 & 0 \\
\hline & & $\begin{array}{l}80 \\
\%\end{array}$ & $\begin{array}{l}20 \\
\%\end{array}$ & - & - \\
\hline \multirow[b]{2}{*}{2} & \multirow{2}{*}{$\begin{array}{l}\text { Ketepatan } \\
\text { memasangkan tutup } \\
\text { botol angka dengan } \\
\text { pasangannya 1-10 }\end{array}$} & 11 & 4 & 0 & 0 \\
\hline & & $\begin{array}{l}73 \\
\% \\
\end{array}$ & $\begin{array}{l}27 \\
\% \\
\end{array}$ & - & - \\
\hline \multirow[b]{2}{*}{3} & \multirow{2}{*}{$\begin{array}{l}\text { Kemampuan anak } \\
\text { membandingkan tinggi } \\
\text { rendah dengan tutup } \\
\text { botol angka } 1-5 \text { dan } 1 \text { - } \\
10\end{array}$} & 12 & 3 & 0 & 0 \\
\hline & & $\begin{array}{l}80 \\
\%\end{array}$ & $\begin{array}{l}20 \\
\%\end{array}$ & - & - \\
\hline \multirow[b]{2}{*}{4} & \multirow{2}{*}{$\begin{array}{l}\text { Kemampuan anak } \\
\text { menghubungkan tutup } \\
\text { botol angka dengan } \\
\text { lambang bilangan } 10\end{array}$} & 11 & 4 & 0 & 0 \\
\hline & & $\begin{array}{l}73 \\
\%\end{array}$ & $\begin{array}{l}27 \\
\%\end{array}$ & - & - \\
\hline & & \multicolumn{2}{|c|}{ Tuntas } & \multicolumn{2}{|c|}{$\begin{array}{l}\text { Tidak } \\
\text { Tuntas }\end{array}$} \\
\hline
\end{tabular}

Sumber pengelola data KB Bina Ana Prasa III Samarinda (2017)

Tabel 5. Hasil Persentase

Keberhasilan Anak Siklus II

\begin{tabular}{|c|l|c|c|}
\hline Skor & \multicolumn{1}{|c|}{ Kriteria } & $\begin{array}{c}\text { Jumlah } \\
\text { Anak }\end{array}$ & Persentase \\
\hline 4 & $\begin{array}{l}\text { Berkembang Sangat } \\
\text { Baik }\end{array}$ & 13 & $87 \%$ \\
\hline 3 & $\begin{array}{l}\text { Bekembang Sesuai } \\
\text { Harapan }\end{array}$ & 3 & $13 \%$ \\
\hline 2 & Mulai Berkembang & - & - \\
\hline 1 & Belum Berkembang & - & - \\
\hline Jmlh & \multicolumn{3}{|c|}{ kemampuan } \\
\hline \multicolumn{4}{|c|}{ Hasil penilaian } \\
\hline
\end{tabular}

mengenal lambang bilangan pada Siklus

II pertemuan 4 hasil persentase keberhasilan anak yaitu kriteria berkembang sangat baik 13 anak mencapai $87 \%$, kriteria berkembang sesuai harapan 3 anak mencapai 13\%

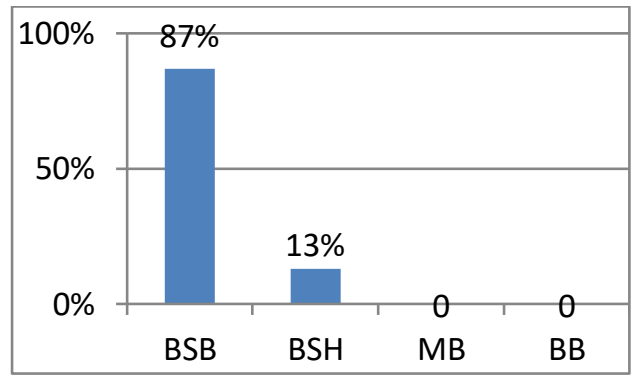

Gambar 2. Diagram Persentase Mengenal Lambang Bilangan 1-10 Pada Siklus II Kriteria Mengenal Lambang Bilangan
Berdasarkan diagram di atas dapat dilihat peningkatan kemampuan mengenal lambang bilangan yang mendapat kriteria berkembang sangat baik 13 anak dengan persentase $87 \%$ dan kriteria berkembang sesuai harapan 2 anak dengan persentase 13\%. Dari hasil tersebut dapat dikatakan bahwa pelaksanaan tindakan siklus II telah memuaskan sehingga tindakan penelitian tidak perlu dilanjutkan lagi. Adapun hasilnya adalah sebagai berikut:

(1) Materi yang disampaikan sudah menarik perhatian anak

(2) Kreatifitas guru dapat menciptakan suasana belajar yang menyenangkan untuk anak

(3) Proses pembelajaran yang dilakukan sudah memasukan unsur bermain, sehingga anak aktif dalam bermain dan tercipta pembelajaran yang menyenangkan bagi anak

(4) Anak yang masih ingin bermain telah disiapkan alat main yang sama sehingga tidak menggangu teman yang lain

Dari hasil refleksi yang diperoleh pada siklus II maka dapat disimpulkan bahwa bermain tutup botol angka untuk meningkatkan kemampuan mengenal lambang bilangan 1-10 pada anak Kelompok A KB Bina Ana Prasa III Samarinda telah berhasil dilaksanakan dan telah memenuhi kriteria 
keberhasilan yang telah menjadi tujuan penelitian. Sebagian besar anak Kelompok A telah mampu mengenal lambang bilangan dengan sangt baik yaitu dari 15 anak, 13 anak telah mengenal lambang bilangan pada kriteria Berkembang Sangat Baik dan 2 anak pada kriteria Berkembang Sesuai Harapan. Hasil yang diperoleh bahwa anak yang memiliki kemampuan mengenal lambang bilangan 1-10 pada kategori Berkembang Sangat Baik mencapai $87 \%$ dan $13 \%$ anak pada kriteria berkembang sesuai harapan. Hasil yang diperoleh pada peningkatan kemampuan mengenal lambang bilangan anak telah mencapai indikator keberhasilan dalam penelitian ini. Dengan melihat hasil perkembangan kemampuan anak mengenal lambang bilangan 1-10 pada siklus II, peneliti memutuskan untuk menghentikan tindakan penelitian.

\section{Pembahasan Hasil Penelitian}

Dari hasil pembelajaran Siklus I terlihat bahwa terjadi peningkatan persentase berkembang sangat baik dan berkembang sesuai harapan dalam mengenal lambang bilangan. Selain itu nampak bahwa pada Siklus I ini terjadi penurunan persentase siswa yang belum bisa mengenal lambang bilangan. Berdasarkan indikator keberhasilan dapat disimpulkan bahwa pembelajaran
Siklus I sudah berhasil seperti yang diharapkan, namun untuk mendapatkan data yang vailid dan hasil yang memuaskan maka penelitan akan dilanjutkan ke siklus selanjutnya yaitu Siklus II.

Pada Siklus II pertemuan pertama dan kedua, kegiatan pembelajaran mengelompokan tutup botol angka dibuat lebih menyenangkan yaitu dengan tutup botol angka mengelilingi gambar yang ada ditengah, ketika memasangkan media yang digunakan botol angka dibuat tiga perempat sehingga mudah untuk di pasangkan dengan tutup botol angka, membandingkan dan menghubungkan medianya masih sama. Dari hasil yang diperoleh pada pembelajaran Siklus II pada pertemuan pertama dan kedua ada dua anak yang mengalami peningkatan berkembang sangat baik dalam mengenal lambang bilangan 1-10.

Menanggapi perolehan hasil pada pertemuan pertama dan kedua tersebut, pada pertemuan ketiga dan keempat media yang digunakan ditambah lagi pariasinya, botol yang digunakan diganti bentuk yang berbeda dan warnanya juga berbeda, ketika menghubungkan tutup botol angka dengan lambang bilangan menggunakan media yang berbeda yaitu anak secara tidak langsung akan mengenal lambang bilangan secara urut, 
anak juga dapat mengetahui jumlah benda yang sesuai dengan lambang bilangan 1-10 sehingga anak akan mengenal lambang bilangan dengan sangat baik. Hasil pembelajaran Siklus II pertemuan keempat menunjukan $87 \%$ anak berkembang sangat baik dan 13\% berkembang sesuai harapan pada Kelompok A KB Bina Ana Prasa III Samarinda telah mengenal lambang bilangan dengan sangat baik. Jika mengacu pada indikator keberhasilan maka pembelajaran Siklus II dikatakan berhasil dan tuntas.

Tabel 6. Rekapitulasi Keberhasilan Kemampuan Mengenal Lambang Bilangan Siklus II

\begin{tabular}{|c|c|c|c|c|c|c|c|c|}
\hline \multirow{3}{*}{$\begin{array}{c}\text { Kriter } \\
\text { ia }\end{array}$} & \multicolumn{8}{|c|}{ Siklus II } \\
\hline & \multicolumn{2}{|c|}{$\begin{array}{c}\text { Pertemuan } \\
1 \\
\end{array}$} & \multicolumn{2}{|c|}{$\begin{array}{c}\text { Pertemuan } \\
2\end{array}$} & \multicolumn{2}{|c|}{$\begin{array}{l}\text { Pertemu } \\
\text { an } 3\end{array}$} & \multicolumn{2}{|c|}{$\begin{array}{c}\text { Pertemu } \\
\text { an } 4\end{array}$} \\
\hline & $\begin{array}{c}\mathrm{jml} \\
\mathrm{h}\end{array}$ & $\%$ & $\begin{array}{c}\mathrm{jml} \\
\mathrm{h}\end{array}$ & $\%$ & $\underset{\mathrm{h}}{\mathrm{jml}}$ & $\%$ & $\begin{array}{l}\mathrm{j} \\
\mathrm{m} \\
\mathrm{l} \\
\mathrm{h}\end{array}$ & $\%$ \\
\hline BSB & 7 & $\begin{array}{l}47 \\
\%\end{array}$ & 8 & $\begin{array}{l}53 \\
\%\end{array}$ & 11 & $\begin{array}{l}7 \\
3 \\
\%\end{array}$ & $\begin{array}{l}1 \\
3\end{array}$ & $\begin{array}{l}87 \\
\%\end{array}$ \\
\hline BSH & 6 & $\begin{array}{l}40 \\
\%\end{array}$ & 6 & $\begin{array}{l}40 \\
\%\end{array}$ & 4 & $\begin{array}{l}2 \\
7 \\
\%\end{array}$ & 2 & $\begin{array}{l}13 \\
\%\end{array}$ \\
\hline MB & 2 & $\begin{array}{l}13 \\
\%\end{array}$ & 1 & 7 & - & - & - & - \\
\hline BB & - & - & - & - & - & - & - & - \\
\hline Total & 15 & $\begin{array}{l}10 \\
0 \%\end{array}$ & 15 & $\begin{array}{l}10 \\
0 \%\end{array}$ & 15 & $\begin{array}{l}1 \\
0 \\
0 \\
\%\end{array}$ & $\begin{array}{l}1 \\
5\end{array}$ & $\begin{array}{l}10 \\
0 \%\end{array}$ \\
\hline
\end{tabular}

Sumber : Hasil Peelitian Tahun 2017
Tabel.7. Rekapitulasi Data Hasil

Observasi Kemampuan Mengenal Lambang Bilangan 1-10 Pra Tindakan,

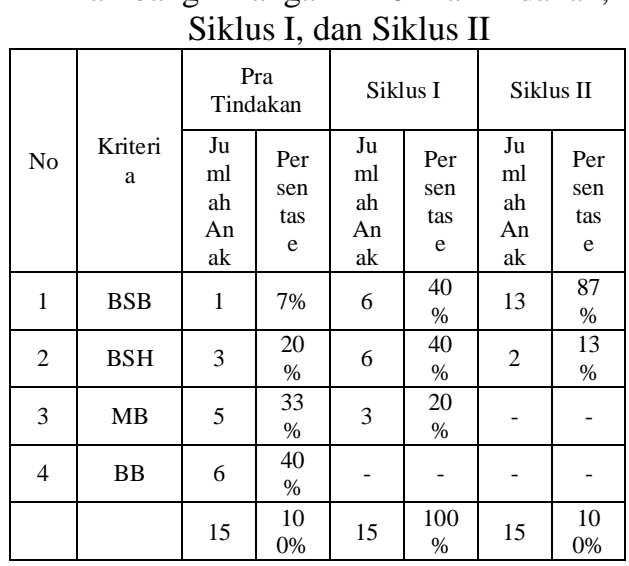

Dari data rekapitulasi hasil observasi kemampuan mengenal lambang bilangan pada tabel 4.22, maka menujukan adanya peningkatan kemampuan anak mengenal lambang bilangan 1-10 dari pra tindakan sampai Siklus II. Untuk lebih jelasnya dapat dilihat pada Gambar berikut ini:

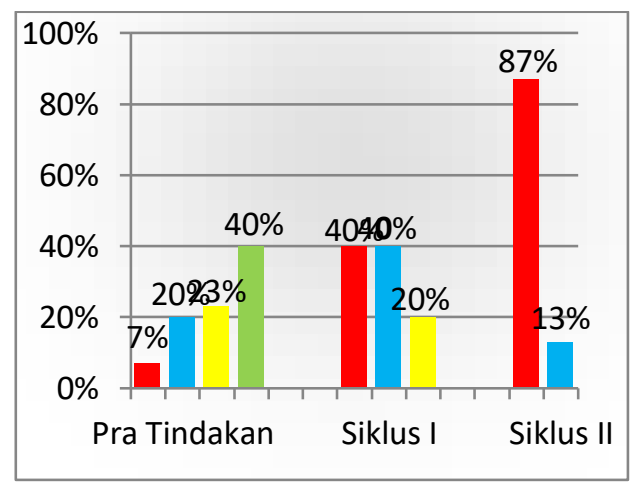

Gambar 3. Diagram Persentase

Kemampuan Mengenal Lambang Bilangan Anak Pra Tindakan, Siklus I, dan Siklus II

Keterangan

$\bullet=$ BSB

$\bullet=\mathrm{BHH}$

$=\mathrm{BB}$

Setelah melihat hasil data kemampuan anak Kelompok A KB Bina Ana Prasa III Samarinda dalam 
mengenal lambang bilangan 1-10 pada grafik di atas dapat diketahui bahwa bermain tutup botol angka dapat meningkatkan kemampuan anak dalam mengenal lambang bilangan. Hal ini dapat dilihat dari peningkatan persentase kemampuan mengenal lambang bilangan anak setelah dilakukan pembelajaran dengan bermain tutup botol angka. Kemampuan mengenal lambang bilangan 1-10 pada anak Kelompok A mengalami peningkatan yaitu anak yang memiliki kemampuan mengenal lambang bilangan 1-10 berkembang sangat baik pada tahap sebelum tindakan $7 \%$ dan berkembang sesuai harapan $20 \%$ dengan persentase keseluruhan 27\%. Siklus I sebanyak $40 \%$ berkembang sangat baik dan $40 \%$ berkembang sesuai harapan dengan persentase keseluruhan mencapai $80 \%$. Dan Siklus II mengalami peningkatan menjadi $87 \%$ berkembang sangat baik dan $13 \%$ berkembang sesuai harapan dengan persentase keseluruhan $100 \%$. Dengan begitu, bermain tutup botol angka dapat meningkatkan kemampuan anak dalam mengenal lambang bilangan 1-10.

Berdasarkan hasil observasi yang dilakukan pada siklus II, dapat dinyatakan bahwa bermain tutup botol angka dapat meningkatkan kemampuan mengenal lambang bilangan pada anak.
Dalam penelitian ini bermain tutup botol angka dilakukan untuk menstimulasi kemampuan mengenal lambang bilangan anak. Mengenal lambang bilangan merupakan materi pembelajaran yang bersifat abstrak. Anak Kelompok A adalah anak yang berusia 4-5 tahun, anak pada usia ini menurut Piaget (dalam Misyati, 2013: 110) berada pada tahap praoperasional yaitu pada tahap ini, berpikir anak masih pada tahap berpikir konkret. Anak tahap praoperasional akan sulit diajak untuk berpikir abstrak. Hal ini sesuai dengan pendapat Piaget (dalam Misyati, 2013: 110) bahwa seseorang tidak dapat belajar sesuatu yang berada diluar tahap kognitifnya. Oleh karena itu, bermain tutup botol angka tepat dilakukan untuk menstimulasi kemampuan mengenal lambang bilangan anak karena untuk mengenal materi yang bersipat abstrak diperlukan media yang mampu mengkonkretkan materi yang disampaikan.

Kegiatan pembelajaran melalui bermain menggunakan tutup botol angka yang dibuat sesuai dengan tahap berpikir anak, menjadikan anak lebih mudah dalam mengenal lambang bilangan. Hal ini sesuai dengan yang dikemukakan Bruner (dalam Misyati, 2013:111) yaitu anak usia dini berada pada tahap ikonik yaitu anak usia dini sudah mampu 
belajar menggunakan simbol-simbol, sehingga tepat sekali apabila belajar dilakukan menggunakan tutup botol angka. Namun tutup botol angka merupakan media visual yang hanya melibatkan indera penglihatan saja, sehingga dibutuhkan suatu metode pembelajaran yang mengaktifkan anak dalam pembelajaran. Bermain salah satu metode yang tepat yang mampu mengaktifkan anak dalam pembelajaran.

Pengenalan lambang bilangan 110 pada anak Kelompok A KB Bina Ana Prasa III Samarinda yang dilakukan dengan bermain tutup botol angka, selain memudahkan anak dalam mengenal lambang bilangan juga mampu meningkatkan antusias belajar anak, belajar anak lebih menyenangkan sehingga menjadikan anak mudah menerima apa yang dipelajari. Oleh karena itu bermain tutup botol angka dapat meningkatkan kemampuan mengenal lambang bilangan 1-10 anak Kelompok A KB Bina Ana Prasa III Samarinda Tahun Pembelajaran 2017/2018.

\section{PENUTUP}

\section{Kesimpulan}

Berdasarkan penelitian tindakan kelas yang telah dilaksanakan dalam dua siklus yaitu Siklus I dan Siklus II, maka dapat disimpulan bahwa kemampuan mengenal lambang bilangan pada anak
Kelompok A di KB Bina Ana Prasa III Samarinda Tahun Ajaran 2017/2018 dapat meningkat melalui bermain tutup botol angka. Hal ini ditandai oleh peningkatan persentase hasil belajar siswa yang memperoleh kriteria berkembang sangat baik (skor 4) yaitu dari $7 \%$ pada saat sebelum siklus menjadi $40 \%$ pada siklus I kemudian meningkat menjadi $87 \%$ pada siklus II. Hal ini membuktikan bahwa peningkatan kemampuan mengenal lambang bilangan dengan bermain tutup botol angka pada anak, ini dikarenakan media yang digunakan yaitu tutup botol angka dapat menarik perhatian anak serta kreativitas guru dapat menciptakan suasana belajar mengajar yang menyenangkan dan penyampaian materi sudah sesuai dengan kemampuan anak.

\section{Saran-Saran}

Berdasarkan pada latar belakang permasalahan yang diuraikan sebelumya, serta data yang diperoleh setelah melakukan penelitian tindakan kelas, maka peneliti menyarankan halhal sebagai berikut:

1. Untuk Anak dapat mengikuti kegiatan bermain tutup botol angka secara aktif agar dapat meningkatkan kemampuan mengenal lambang bilangan pada anak. 
2. Untuk Guru agar selalu meningkatkan mutu dalam kegiatan belajar mengajar, juga aktif dan kreatif dalam membuat media pembelajaran walaupun dari barang bekas yang dapat dimanfaatkan, dapat memberikan kemudahan dalam mengenal lambang bilangan sehingga anak-anak bermain dengan suasana menyenangkan.

3. Untuk Sekolah: Bagi Kepala Sekolah diharapkan dapat memotivasi dan membimbing guru lebih baik didalam membuat perangkat mengajar, menentukan metode dan media, bahan, yang tepat bagi anak didik.

\section{DAFTAR PUSTAKA}

Arikunto Suharsimi, 2006. Penelitian Tindakan Kelas. Jakarta: Rineka Cipta.

Dimyati, J. 2014. Metologi Penelitian.

Pendidikan\&Aplikasinya Pada Pendidikan Anak Usia Dini. Jakarta: Penerbit Kencana.

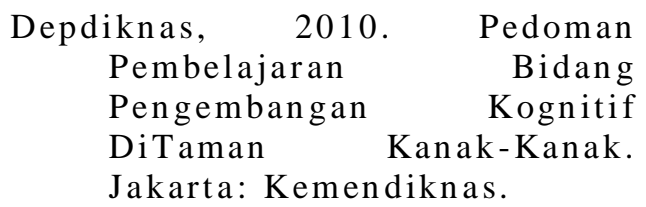

Kementrian Pendidikan dan Kebudayaan, 2015 Buku Panduan Pendidik Kurikulum 2013 PAUD Anak Usia 4-5 Tahun. Pusat Kurikulum Dan Pembukuan. Badan Penelitian dan Pengembangan.
Khadijah, 2016. Pengembangan Kognitif Anak Usia Dini. Medan: Penerbit Perdana Mulyasa Sarana.

Kartika Mayasari, 2012. Pengaruh Penggunaan Balok-Balok Angka Terhadap Kemampuan Mengenal Lambang Bilangan. Pada Anak Kelompok A Di TK Aisyiah Bustanul Athfal 7 Padan Bandung Dukun Gresik. PG PAUD Universitas Negeri Surabaya. Jurnal Mahasiswa (Online), Jilit II, Nomor 05 unesa.ac.id >article.diakses 05 Juni 2017.

Najib. 2016. Manajemen Strategik Pendidikan Karakter. Bagi Anak Usia Dini. Yogyakarta: Penerbit Gava Media.

Ningsih, Amin. 2015. Meningkatkan Kemampuan Berhitung 1-20 Dengan Menggunakan Media Tutup Botol. Pada Kelompok B PAUD Dharma Putra Kecamatan Gurah Kabupaten Kediri. PG PAUD FKIP .(Online), https://SIMKl.1PZM.Unpkediri.a c.id.file. Diakses 09 Juli 2017.

Normala R. Kolly, 2012. Meningkatkan Kemampuan Mengenal Lambang Bilangan 1-10 Dengan Menggunakan Media Konkret Penutup Botol. Pada Kelompok A Cempaka Putih Gorontalo Utara. PGPAUD FIP UNG

Misyati, Eli. 2015. Peningkatan Kemampuan Mengenal Lambang Bilangan Melalui Bermain Kartu Angka Bergambar Anak A TK Masjid Syuhada Yogyakarta.Artikel Universitas Negri Yogyakarta, (Online), Jilid IV, Nomo $81,110,111$ 
(Eprints.Uny.ac.id > Skripsi, diakses20 Juli 2017).

Patilima, H. 2015. Resiliensi Anak Usia Dini. Bandung: Penerbit Alfabeta.

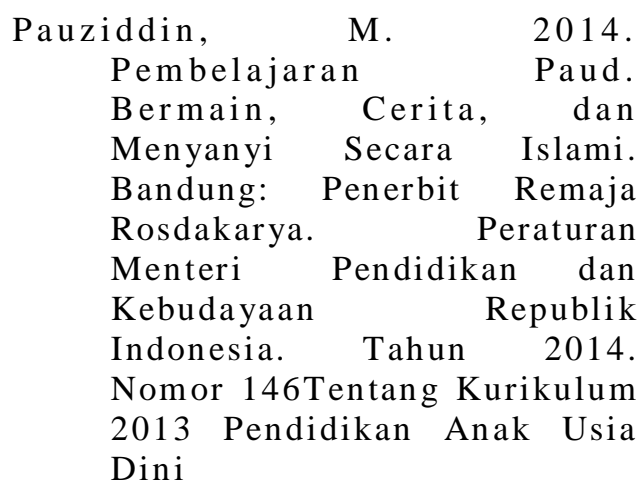

Soemiarti, P. 2008. Pendidikan Anak Prasekolah. Jakarta Penerbit Rineka Cipta.

Sriningsih. 2009. Pembelajaran Matematika Terpadu Anak Usia Dini Bandung Penerbit Pustaka Sebelas.

Sudarna. 2014. Psikologi. PAUD Pendidikan Anak Usia Dini Berkarakter. Melejitkan Kepribadian Anak Secara Utuh (Kecerdasan Emosi, Spirit, dan Sosial) Perpustakaan Nasional RI: Katalok Dalam Terbitan (KDT). Yogyakarta: Genius Publisher.

Suryadi. $\quad 2015 . \quad$ Teori Pembelajaran Anak Usia Dini. Dalam Kajian Neurosains. Jakarta: Penerbit PT Remaja Rosdakarya.

Yusuf Sugandhi. 2012. Perkembangan Peserta Didik. Jakarta: Penerbit Raja Grafindo Persada 
